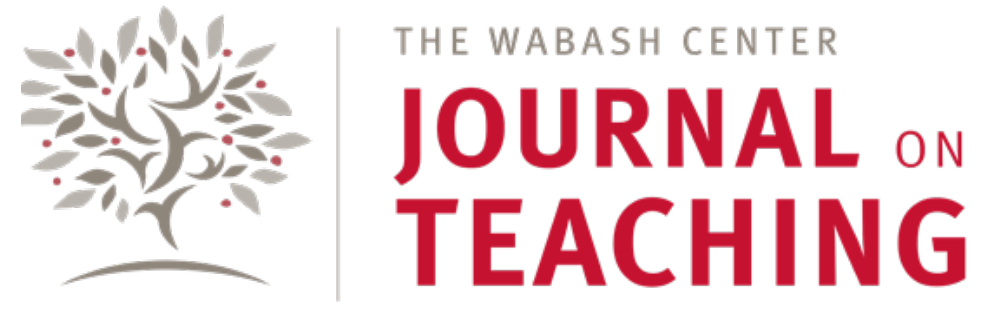

F O R U M

\title{
Learning Theology in the Struggle for Freedom
}

\author{
Colleen Wessel-McCoy \\ Kairos Center for Religions, Rights, and Social Justice
}

\begin{abstract}
In his work as a scholar and educator, James Cone developed leaders. He built a network of scholars, clergy, and activists committed to the power of God in history and to the role of the poor and dispossessed in realizing earthly freedom. Cone's courses began with the situatedness of the theologians being studied and always returned to the problems of the world that theologians sought to answer. He challenged his students to do the same, identifying and answering the crises of our communities, doing theology in the struggle for justice and liberation. This is one of several short essays presented by recent students at a public forum at Union Theological Seminary after his death in 2018.
\end{abstract}

\author{
KEYWORDS \\ James Cone, Martin Luther King Jr, Poor People’s Campaign, poverty, leadership
}

In recent years I have been traveling around to teach about Martin Luther King Jr.'s 1968 Poor People's Campaign as part of today's Poor People's Campaign: A National Call for Moral Revival. My presentation includes a clip from a documentary where Prof. Cone is the featured scholar on King's last years. In the film you can hear him speak before you see his image and name, and there is always an audible stir of excitement as people recognize his voice. And then as his image comes onto the screen that stir breaks into a cheer. Prof. Cone's voice impacts you and taps into all you have learned from him. No matter where I was-north or south, east or west-people recognized his voice, and that's because Prof. Cone's teaching included his role as a public theologian. He was committed to black people, poor people, and oppressed people everywhere. He relentlessly called the world to do and be better, even when he knew it would fail again. But the commitment to transformation that sent him around the world always brought him back to the students of Union Theological Seminary. He believed in us. He believed in our capacity to join him in the prophetic role of the theologian. God grant us the strength to live up to his hopes for us.

The alumni of Union Theological Seminary are leaders in our communities and congregations because we have been shaped by his commitment to us as an educator. He called us to deeper scholarship, challenging the anti-intellectualism that creeps into organizing and activism, into our churches, and even into our classrooms. Because of him we read our Bible differently, we expect scholars and religious leaders to take sides with the oppressed, and we insist that the brokenness of the world cannot be understood apart from systemic racism. His teaching methods drew from this commitment to shaping religious leaders for the world.

As an educator Prof. Cone insisted that we not lift ideas out of the material reality from which they came. Course material and lectures began with the situatedness of the theologians we studied and always returned to the problems and questions the theologians sought to answer. His book and course, Martin \& Malcolm \& America was truly about all three (1991). He extended the session time to preface every class with documentaries that took us to the context of the $1950 \mathrm{~s}$ and $60 \mathrm{~s}$. He 
wanted us to understand that Malcolm and Martin were shaped by the urgent questions of their day. And he wanted us to understand that their contributions were strengthened by that relationship.

As my work moved deeper into the study of the Poor People's Campaign I moved to understand more deeply Prof. Cone's insistence that we underestimate Martin Luther King Jr.'s theological contribution when we fail to see (or refuse to see) that, "the struggle for freedom is the only appropriate context for doing theology" $(1986,21)$. And Prof. Cone challenged us to do the same, identifying and answering the crises of our communities and world.

It was while I served as a teaching fellow for his classes that I realized that to be criticized and challenged by Prof. Cone was a compliment. It meant that he took you seriously and knew that the world needed you to be best you could be. As I come into my own work as an educator I increasingly appreciate his capacity to be critical of students, to tell us when we were wrong or fell short. I watch my own students struggle to learn how to hear corrections and suggestions without being overwhelmed by it. I struggle to learn that myself. But it was always clear that challenges and corrections from Prof. Cone were in the service of making us better scholars, ministers, and justice seekers. Bishop William Barber II reminds the leaders of the Poor People's Campaign: A National Call for Moral Revival, “Don’t be loud and wrong.” Prof. Cone similarly knew from his fight for Black Theology that the oppressed are doubly scrutinized for errors and weaknesses. We must know the dominant voices better than they know themselves and then know our own scholarship as well.

Prof. Cone insisted that we be changed by what we study, not confirmed by it. He taught this by modeling it. He was candid about the times in his life when he was challenged by his colleagues and students. He was always open to hearing new ideas from students-as long as you demonstrated a real understanding of the ideas to which you were responding. He had little patience for superficial challenges, and he had heard them all over the course of his years. As both a student and teaching fellow in Prof. Cone's "Introduction to Theology," I remember the appalling arrogance and racism of some students who shamelessly raised their hands to challenge liberation theologies in ways they would never do for dominant theologies. Prof. Cone responded directly and unapologetically yet somehow also pastorally.

I smile when I think of the stack of well-worn books that he brought to class. He would place them on the table, spine out, and go directly to specific passages as called for by the course of discussion. In some sessions that stack would grow quite tall. In his "Black Theology" course he drew from the theologians directly, even when we had been reading them from his compilation, pulling out the original text to cite. He once observed that I had made reference to material from an endnote encouraging close reading. Students whose questions and comments revealed that they had not fully read or wrestled with the assigned readings before coming to class were redirected to the text.

Part of the story of Prof. Cone's effectiveness as an educator and mentor is the skillful work of his administrative assistant Vicky Furio. She brought to her work a commitment to students, justice, and liberation. It showed in her no-nonsense handling of appointments, papers, and schedules. She made the attention that Prof. Cone gave to students and scholarship possible. I often find her in the acknowledgements section of my peers' dissertations and books and am reminded of my own gratitude.

Cone was a towering global figure and a prophet of freedom. His vocation as a writer and educator was truly a ministry. He took the time to develop new leaders, to build a network of scholars, clergy, and activists committed to liberation, to the power of God in history, and to the role of the poor and dispossessed in realizing earthly freedom. There are generations of us across the country and world. And because of his commitment to developing this broad network of leaders, the tradition continues to build and you are invited into it, even if you didn't take a class with him. Black Theology, rooted in the freedom strands of the black church tradition, asks each of us, "In what ways can we best explicate the meaning of God's liberating activity in the world so that the oppressed will be ready to risk all for earthly freedom?” (Cone 1993, 111).

I miss his wise advisement, his impassioned lectures in the classroom, and his warm kindness as we passed each other in the hallway. But his challenge to be faithful to the God of liberation and to God's people lives and grows. His challenge to faithfulness follows us -in the classroom, the congregation, the community center, the streets, the legislature, and the courts -in every sphere where the poor and dispossessed are breaking out and uniting, ready to risk all for earthly freedom and to claim the promises of the God who takes sides in history. This call remains forever clear, if you are willing to hear it. 


\section{ADDITIONAL CONTRIBUTIONS TO THE FORUM ON DR. JAMES CONE}

Editor. 2020. "Introduction to the Forum on Dr. James H. Cone as Teacher and Mentor." The Wabash Center Journal on Teaching 1(2): 79-80. https://doi.org/10.31046/wabashcenter.v1i2.1501.

\section{BIBLIOGRAPHY}

Cone, James H. 1986. “The Theology of Martin Luther King, Jr.” Union Seminary Quarterly Review 40, (4): 21-39.

Cone, James H. 1991. Martin \& Malcolm \& America: A Dream or a Nightmare. Maryknoll, NY: Orbis Books.

Cone, James H. 1993. “Black Theology and Black Liberation.” In Black Theology: A Documentary History, Volume One: 1966-1979, edited by James H. Cone and Gayraud S. Wilmore, 106-13. Maryknoll, NY: Orbis Books.

\section{ABOUT THE AUTHOR}

Colleen Wessel-McCoy is a lecturer at Union Theological Seminary and Co-coordinator of Poverty Scholarship and Leadership Development at the Kairos Center for Religions, Rights, and Social Justice. A former teaching fellow for Professor James Cone, her scholarship focuses on Martin Luther King Jr.'s political strategy and theological vision of a Poor People's Campaign in 1968 and the work of the organized poor in a revolution of values today. 
